\title{
ESCOLA E TRABALHO NO POSTO INDÍGENA APUCARANA: INDIGENISMO E AÇÃO KAINGANG
}

\author{
SCHOOL AND WORK AT THE APUCARANA \\ INDIGENOUS CENTER: INDIGENISM \\ AND KAINGANG ACTION
}

Éder da Silva Novak*

\begin{abstract}
RESUMO
O presente estudo analisa as relações entre indígenas e não índios do Posto Indígena $(\mathrm{PI})$ Apucarana, no período entre 1942 a 1967. O objetivo central é evidenciar a ação indigenista e a política dos Kaingang perante a estruturação da sede do Posto, no que tange a instalação da escola e a oferta de trabalho aos índios, para prepará-los ao mercado de trabalho regional, utilizando-se da chamada pedagogia da nacionalidade. A pesquisa utilizou-se da documentação produzida pelo Serviço de Proteção aos Índios (SPI), como dados escolares, demográficos, produção agrícola e relatórios diversos. Os resultados revelam as múltiplas estratégias, os jogos de interesses e as tensões entre os sujeitos presentes no PI Apucarana, com destaque ao protagonismo Kaingang, sua leitura e interpretação daquele contexto.
\end{abstract}

PALAVRAS-CHAVE: Pedagogia da Nacionalidade; Escola; Trabalho; Kaingang.

\begin{abstract}
This study analyzes the relations between indigenous and non-indigenous people of the Apucarana Indigenous Center (PI), in the period between 1942 to 1967. The main objective is to highlight the indigenous action and the Kaingang's policy in view of the structure of the Center's headquarters, with regard to the installation of the school and the offer of work to the natives, to prepare them for the regional labor market, using the so-called pedagogy of nationality. The research used the documentation produced by the Indigenous Protection Service (SPI), such as school, demographic, agricultural production data and various reports. The results reveal the multiple strategies, the underlying interests and the tensions between the subjects present in the PI Apucarana, with emphasis on the Kaingang protagonism, its reading and interpretation of that context.
\end{abstract}

KEY WORDS: Pedagogy of Nationality; School; Work; Kaingang.

* Professor da graduação e pós-graduação em História na Universidade Federal da Grande Dourados (UFGD) - Faculdade de Ciências Humanas, Dourados, MS, Brasil. Doutor em História pela UFGD. Mestre e Graduado em História pela Universidade Estadual de Maringá (UEM). E-mail: edernovak@ ufgd.edu.br. 
A Terra Indígena (TI) Apucaraninha, situada no município de Tamarana (Paraná), possui atualmente mais de 1.700 indígenas, a maioria da etnia Kaingang. A extensão territorial da área é de 5.574 hectares (ha) de terras, compreendida na bacia hidrográfica do rio Tibagi, limitada por esse rio e pelos seus afluentes Apucarana e Apucaraninha.

Presentes na região há mais de dois mil anos os Kaingang obtiveram a reserva de suas terras com o advento da República, após a extinção das Colônias Indígenas implementadas pela Província do Paraná. Uma área com aproximadamente 68 mil hectares foi destinada aos indígenas próximos à Serra do Apucarana, delimitada pelos rios Tibagi, Apucarana e Apucaraninha (NOVAK, 2019).

Contudo a área foi sendo invadida por não-indígenas durante a primeira metade do século XX. Nesse tocante deve ser compreendido o Acordo de 1949, quando o Governo do Estado pretendeu reestruturar os territórios indígenas, entre eles o de Apucarana, reduzindo-o consideravelmente e regularizando a posse dos colonos que se instalaram no interior da área destinada aos Kaingang, legitimando a titulação das terras invadidas naquele período de quase cinco décadas (NOVAK, 2018).

Após um período de quase duas décadas de embates, a área do Posto Indígena (PI) Apucarana, no final de 1967, estava regularizada com seus 6.300ha, seguindo o estipulado pelos critérios do Acordo de 1949. De toda forma, a atual Terra Indígena Apucaraninha, que em 1900, foi reservada aos Kaingang com mais de 68.000ha, passou pela reestruturação do Acordo de 1949, ficando com 6.300ha e por outros processos de esbulhos durante o século XX, perdendo mais de 700ha nos anos 1970 e 1980, sendo reduzida aos seus atuais 5.574ha. O Mapa 1 representa a atual Terra Indígena Apucaraninha, revelando a perda substancial de terras no processo de esbulho dos territórios indígenas durante o século XX.

Após essas considerações, a proposta aqui é apresentar e contextualizar a presença do órgão indigenista com a criação do Posto Indígena Apucarana em 1942, até o período de transição SPI/FUNAI, ocorrida em 1967, demonstrando as ações e atividades cotidianas desenvolvidas pelos agentes do SPI, ou seja, a política indigenista, sobretudo no tocante à organização da escola e do trabalho e produção do PI. Da mesma forma, evidenciar as estratégias dos Kaingang, que realizavam sua leitura dos acontecimentos e tinham seus interesses em jogo, estabelecendo suas próprias políticas, provocando um campo de dúvidas e incertezas, por meio de uma abordagem além da visão simplista e polarizada indígenas versus não-indígenas.

\section{A política indigenista no PI Apucarana}

A Diretoria do SPI ficava centralizada no Rio de Janeiro e depois foi para Brasília com a mudança da capital nacional. Regionalmente existiam as Inspetorias Regionais (IRs), como a Sétima Inspetoria Regional (IR7), situada em Curitiba-PR e que administrava dos Postos Indígenas (PIs) situados nos estados de São Paulo,

Revista História em Reflexão, Vol. 15, N. 29 | jan. a jun. de 2021 
Paraná, Santa Catarina e Rio Grande do Sul. Conforme Oliveira e Freire (2006), a FUNAI alterou a denominação IRs para Delegacias Regionais (DRs). 1

Mapa 1 - Os Toldos indígenas e a (des) territorialização dos Kaingang do Apucarana

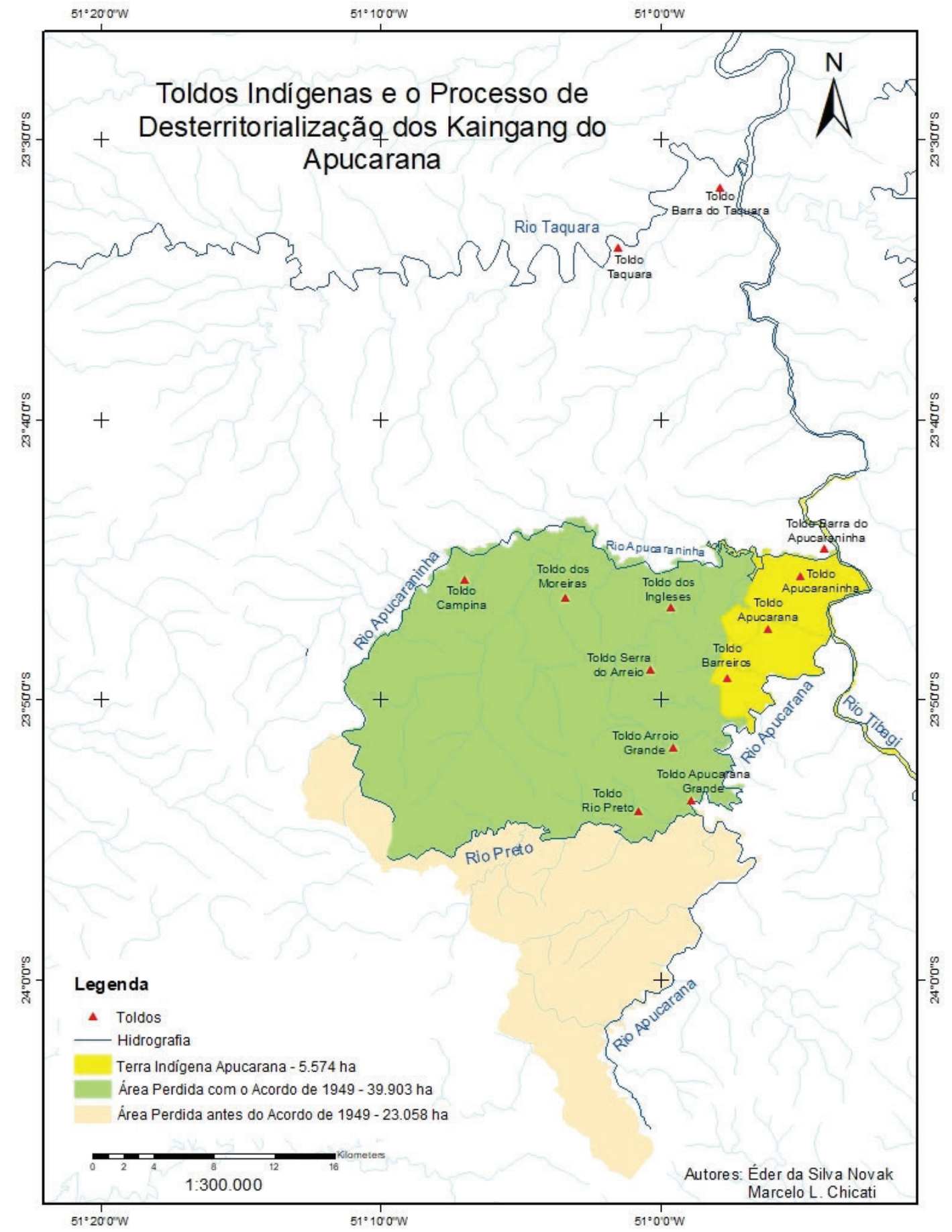

Autores: Éder da Silva Novak e Marcelo L. Chicati.

1 Para mais detalhes dessa estrutura administrativa do SPI e FUNAI e sobre a política indigenista na República ver: Oliveira e Freire (2006); Souza Lima (1998); Rocha (2003); Gagliardi (1989). 
O PI Apucarana foi criado no início de janeiro de 1942. O Memorando no 1, de 6 de janeiro daquele ano, foi enviado pela IR7 ao primeiro encarregado do Posto Francisco Gracia - dando as orientações para as atividades iniciais a serem realizadas. Gracia enviou a folha de pagamento do PI Apucarana Á IR7, com a existência de 3 funcionários: Francisco Gracia, como encarregado; Cristina Vulcanis Gracia, como auxiliar de ensino, esposa do encarregado; e o índio Luiz Pereira, como aprendiz (SPI, 01/01/1943, Filme 47, Fotogramas 27-28).

Imediatamente após a criação do PIApucarana, a IR7 solicitou que o encarregado Francisco Gracia se dedicasse a construção da escola, da enfermaria, à criação de gado, porcos e aves e que desse alimentos, roupas e comida aos alunos indígenas, dando andamento às obras necessárias para a estruturação do PI Apucarana (SPI, 06/01/1942, Filme 73, Fotograma 1512). Essa infraestrutura era essencial, conforme Oliveira e Freire (2006), para garantir o sucesso da política indigenista, que visava à assimilação e integração do índio à sociedade nacional.

Os agentes do órgão indigenista buscavam atrair os indígenas para próximo da sede do Posto. Assim, realizavam recenseamentos que evidenciam a existência de diferentes Toldos (territórios com aldeias Kaingang) em grande parte da área reservada aos indígenas, inclusive fora dessa área, conforme demonstra o Mapa 1.

Tabela 1 - Recenseamento dos índios do PI Apucarana em Julho de 1943

\begin{tabular}{|l|c|}
\hline Toldo & Total de indígenas \\
\hline Campina - Sede do Posto & 19 \\
\hline Bairro dos Moreiras & 17 \\
\hline Ribeirão do Inglês & 17 \\
\hline Barreiro & 15 \\
\hline Apucarana & 61 \\
\hline Rio Preto & 55 \\
\hline & 184 \\
\hline
\end{tabular}

Fonte: SPI, 20/07/1943, Filme 47, Fotogramas 168-187.

Em relação ao Toldo Campina, o mais próximo da sede do Posto, o agente Deocleciano Nenê relatou:

\begin{abstract}
Os índios apenas encontram-se morando nas proximidades do Posto só 5 famílias, isso mesmo 2 casaes não são moradores efetivos, eu recenciei eles como sendo moradores, porem estão ali provisoriamente, mas, dos moradores quase efetivos possuem 9 suinos e 5 equinos. As aguas são boas, tendo nessa área alguns arroios que correm pelo centro (SPI, 20/07/1943, Filme 47, Fotograma 161).
\end{abstract}

De um total de 19 índios no Toldo Campina, dois casais não eram moradores efetivos, ou seja, um número pequeno de indígenas habitava perto do local onde se erguia a estrutura da sede do PI Apucarana. 

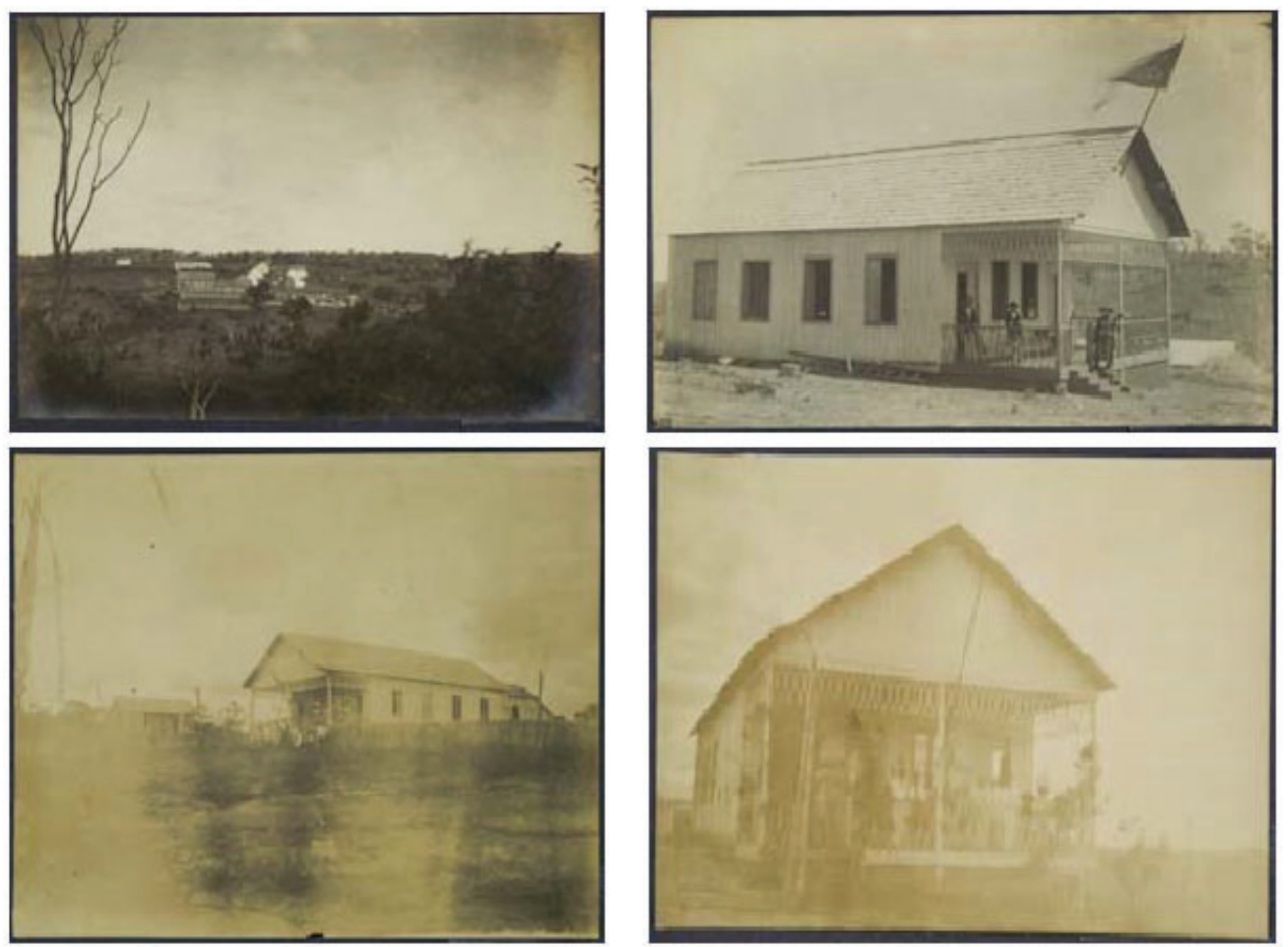

Fonte: SPI, 1942-1967.

Francisco Gracia relatou que 16 alqueires de roça haviam sido preparados, onde foram plantados milho, arroz e feijão, além de uma grande horta. Narrou também a compra de animais para o Posto, como porcos, aves, cabra, cavalos, touro e vacas. $\mathrm{O}$ encarregado ainda assinalou a presença de uma invernada para a criação de animais, próximo ao rio Apucaraninha, além de outras providências para o desenvolvimento da agricultura, já que as terras eram magníficas, com pinheirais gigantescos e madeira de lei de várias espécies (SPI, 01/01/1943, Filme 47, Fotogramas 136-137). Como visto, se vislumbrava a possibilidade de extração da madeira para ganhos econômicos. Essa ação se encaixava na política indigenista do SPI, que cobrava dos PIs a autonomização econômica (SOUZA LIMA, 1992, p. 164).

Quadro 2 - Encarregados do PI Apucarana entre 1942 a 1967

\begin{tabular}{|l|l|}
\hline Ano & Nome do Encarregado \\
\hline 1942 & Francisco Gracia \\
\hline 1943 & João Martins Neto \\
\hline 1951 & Alan Cardec Martins Pedrosa \\
\hline 1964 & João Garcia de Lima \\
\hline 1967 & Jonas Batista de Carvalho \\
\hline
\end{tabular}

Fonte: Elaborado pelo autor. 
Quadro 3 - Fotografias do gado e das plantações no PI Apucarana
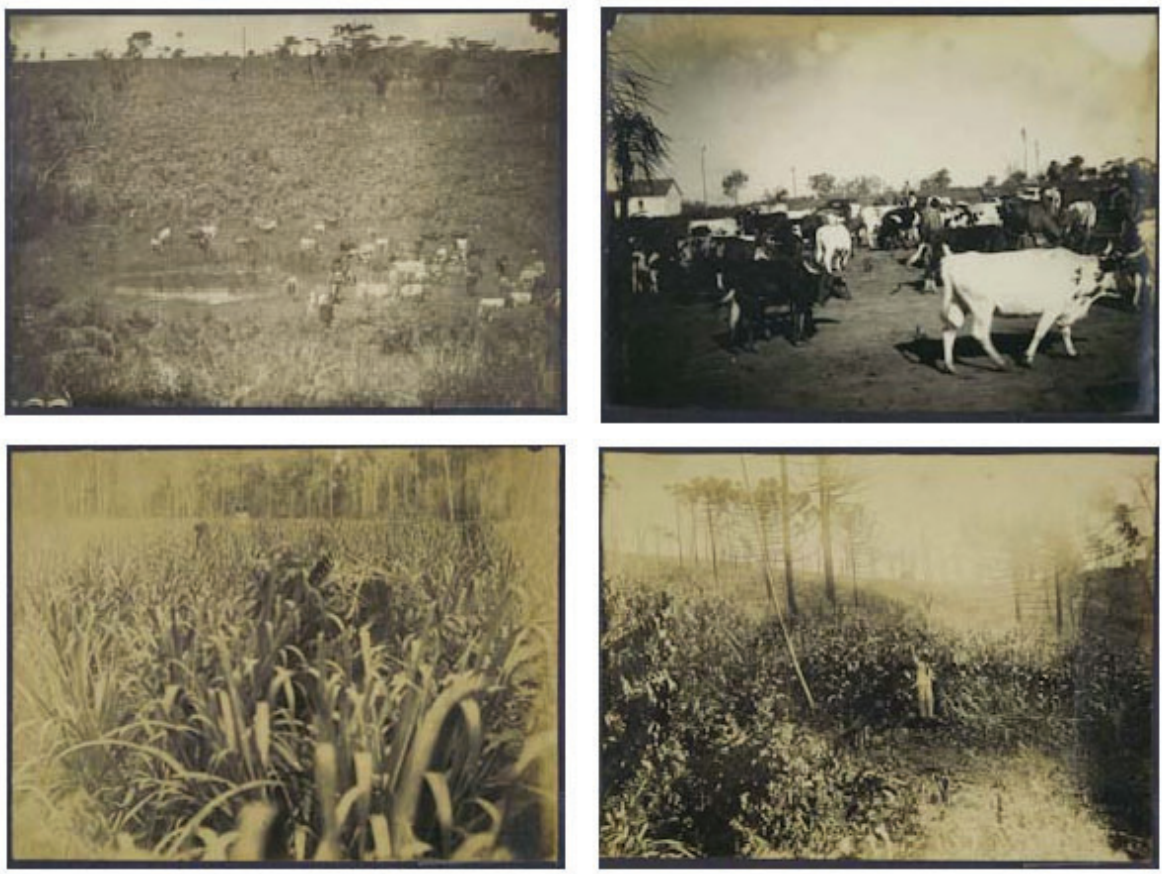

Fonte: SPI, 1942-1967.

Ao final de 1944, o encarregado João Martins Neto enviou ao chefe da IR7, Paulino de Almeida, o Relatório Anual das ocorrências e serviços do Posto, informando a existência de [...] 30 predios construídos [...] e coberto também com taboinhas de pinho lascasdo e que estão servindo para Casa da Administração, casa para empregados, galpão para arames e ferramentas, estrebaria, paiol para cereais e casa para moradia de índios (SPI, 16/12/1944, Filme 47, Fotogramas 591-592).

Entremeio a esses Relatórios, Martins Neto enviou ao diretor do SPI, José Maria de Paula, no Rio de Janeiro, os dados do arrendamento de terras do PI Apucarana, constando um número total de 569 foreiros, também chamados de fogões, deixando evidente um número maior de não-índios vivendo no território reservado aos Kaingang (SPI, 31/01/1946, Filme 47, Fotogramas 1694-1696).

Como observado, os dados demográficos da área indígena eram muito valorizados pelo órgão indigenista. O Ofício n 14 , de 30 de abril de 1946, enviado pelo encarregado do PI Apucarana ao diretor do SPI, Dr. José Maria de Paula, comunicou a realização de um recenseamento de todos os indígenas do PI Apucarana, a pedido da IR7, levantando informações sobre as roças, criação de animais, saúde dos indígenas e dados escolares (SPI, 30/04/1946, Filme 47, Fotograma 1830).

Este recenseamento foi encerrado em junho de 1946, com os resultados enviados a Diretoria do SPI, por meio do Ofício $\mathrm{n}^{\circ} 22$, apresentando um total de 288 índios, entre homens, mulheres e crianças, demonstrando a idade, sexo, etnia, Toldo, nome em português, indígena etc. (SPI, 30/06/1946, Filme 47, Fotograma 1838). 


\section{Quadro 4 - Fotografias de indígenas Kaingang no PI Apucarana}
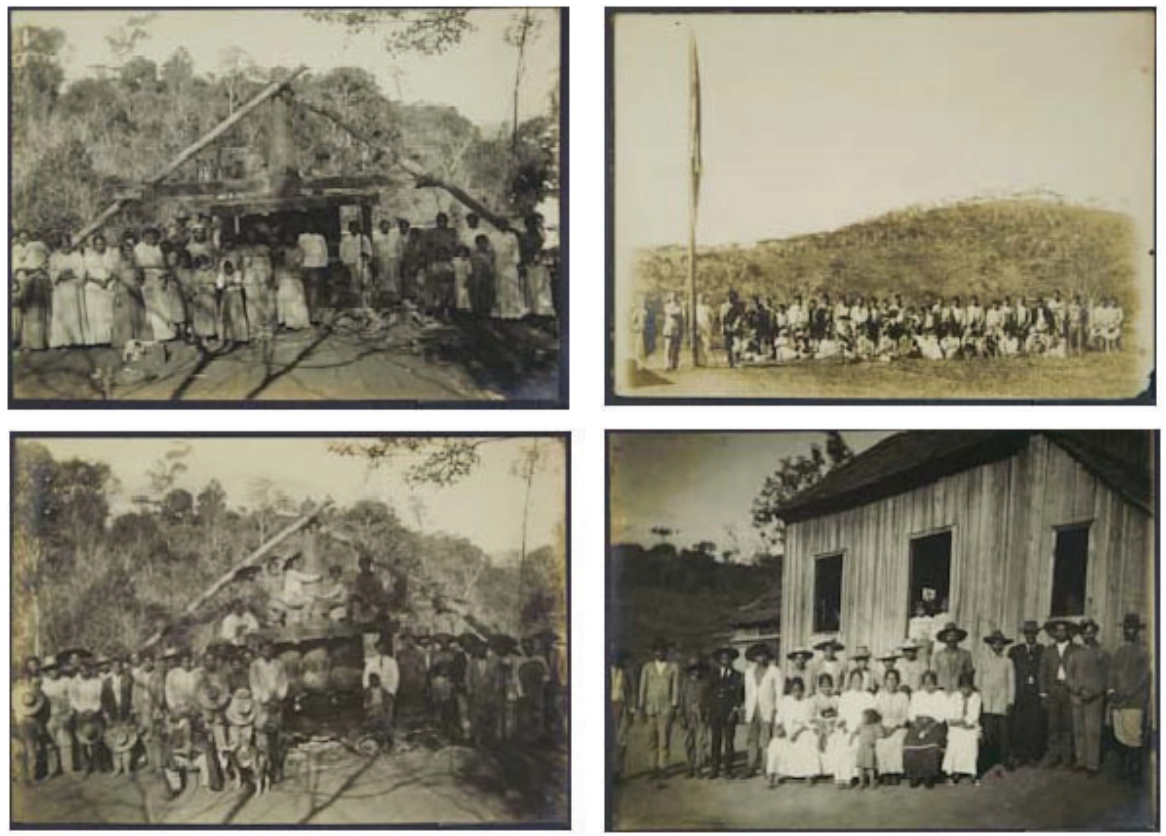

Fonte: SPI, 1942-1967.

Como já visto, além do recenseamento dos indígenas, o SPI também procedia a contagem dos não-índios. Em 15 de dezembro de 1950, por exemplo, o PI Apucarana enviou uma Relação dos Intrusos Domiciliados na Reserva Indígena Apucarana, com os nomes de 367 foreiros (SPI, 15/12/1950, Filme 48, Fotogramas 1465-1467). Era o contexto de negociações da nova área destinada aos índios, decorrente do Acordo de 1949², e mais uma vez o número de não-índios era muito maior que a população indígena daquele Posto, ficando claro o que Oliveira (1988) chamou de paradoxo de tutela: afinal o SPI estava para defender o indígena ou os não-indígenas presentes no interior das áreas destinadas aos primeiros?

Tabela 2 - Recenseamentos dos índios do PI Apucarana

\begin{tabular}{|l|c|l|}
\hline Data & Total de Índios & Fonte \\
\hline $31 / 12 / 1943$ & 283 & SPI, 31/12/1943, Filme 47, Fotograma 221 \\
\hline $31 / 03 / 1948$ & 305 & SPI, 31/03/1948, Filme 48, Fotograma 807 \\
\hline $31 / 01 / 1950$ & 293 & SPI, 31/01/1950, Filme 48, Fotograma 1388 \\
\hline $31 / 01 / 1955$ & 282 & SPI, 31/01/1955, Filme 48, Fotograma 1840 \\
\hline $31 / 05 / 1960$ & 225 & SPI, 31/05/1960, Filme 68, Fotograma 1941 \\
\hline $31 / 01 / 1964$ & 300 & SPI, 31/01/1964, Filme 68, Fotograma 2167 \\
\hline $31 / 01 / 1967$ & 227 & SPI, 31/01/1967, Filme 69, Fotograma 178 \\
\hline
\end{tabular}

Fonte: Elaborada pelo autor.

2 Ver mais detalhes sobre o Acordo de 1949 e o Território Indígena Apucarana em: Novak (2018).

Revista História em Reflexão, Vol. 15, N. 29 | jan. a jun. de 2021 
Conforme Oliveira e Freire (2006), o SPI praticamente copiou as ideias das reduções jesuítas dos séculos XVI/XVII e dos aldeamentos indígenas do XIX, no sentido de querer agrupar os indígenas em pequenas áreas de terras que [...] funcionaram mais como reserva de mão de obra do que favoreciam a reprodução socioeconômica dos índios (OLIVEIRA; FREIRE, 2006, p. 122). Entretanto, como demonstrou Cunha (1992), frente a política indigenista se desenvolveu também a política indígena e esta, muitas vezes, não era convergente com o planejamento do órgão indigenista, como os deslocamentos para outros Pls.

Como é de conhecimento de V.S., os nossos índios conservando os seus velhos e tradicionais costumes, continuam desta forma, deixando os encarregados de Postos em eterna dificuldade, visto os mesmos, dado o seu estado nómade, viverem sempre em mudanças de um Posto para outro, razão porque dificilmente podemos fornecer o numero exato da população de cada PI; no entretanto, mas dificel se tornaria a situação, se privasse-mos os mesmos de seus velhos hábitos (SPI, 04/08/1956, Filme 48, Fotograma 1977).

Em virtude do processo de reestruturação do território indígena do Apucarana, o SPI necessitou alterar a sede do Posto. Primeiramente, em novembro de 1951, o encarregado Alan Cardec comunicou a construção da nova sede do PI Apucarana no Toldo do Capitão Luiz, na Água do Gregório e também a conclusão da estrada que ligava a nova sede ao Bairro da Usina (SPI, 30/11/1951, Filme 48, Fotogramas 14921493) ${ }^{3}$. A sede do PI Apucarana mudaria novamente de local a partir de outubro de 1952, mantendo-se presente no mesmo local até os dias atuais ${ }^{4}$

Buscando diferentes formas de se reestruturar e de aumentar a renda, o PI Apucarana apostou na construção de uma olaria, como demonstra o Ofício $n^{\circ} 24$, de 7 de junho de 1966, que funcionaria dentro da área indígena, com boas perspectivas de renda para o SPI e aos índios, mas que necessitava de autorização e liberação dos recursos para o pagamento dos custos necessários para a instalação da olaria (SPI, 07/06/1966, Filme 49, Fotogramas 150-151).

Em terras reduzidas, após a definição dos 6.300ha destinados ao PI Apucarana, o encarregado Jonas Batista Carvalho, por meio do Ofício no 13 , de 5 de dezembro de 1967, relatou as plantações e lavouras do Posto, mas afirmou que [...] as possibilidades de rendas só com funcionamento da serraria e olaria, ou madeiras brutas e beneficiadas (SPI, 05/12/1967, Filme 69, Fotograma 324). Dessa forma, é evidente que as lavouras e as plantações já não tinham a mesma importância de quando a área indígena era maior e possuía maior quantidade de solos apropriados para a agricultura.

Da mesma forma, o Ofício n 31, de 21 de agosto de 1967, comunicou que a área indígena estava legalizada e demarcada, sem litígios, com 6.300ha, totalizando 229 índios, sendo 218 Kaingang, 5 Botocudo e 6 Carijó, todos pacificados (SPI,

3 Essa sede provisória estava situada nas proximidades do Toldo Apucarana, dentro da área atual da Terra Indígena Apucaraninha (Ver Mapa 1).

4 Essa sede foi instalada nas proximidades do Toldo Apucaraninha (Ver Mapa 1) e permanece atualmente na mesma localidade, sendo a sede da Terra Indígena Apucaraninha. 
21/08/1967, Filme 69, Fotogramas 295-297). A ideia de índio pacificado, explica Souza Lima (1992), era o pensamento do órgão indigenista em transformar o silvícola em trabalhador nacional, sujeito engajado e produtivo, na perspectiva de homogeneização cultural.

Quadro 5 - Fotografias de máquinas e olaria no PI Apucarana
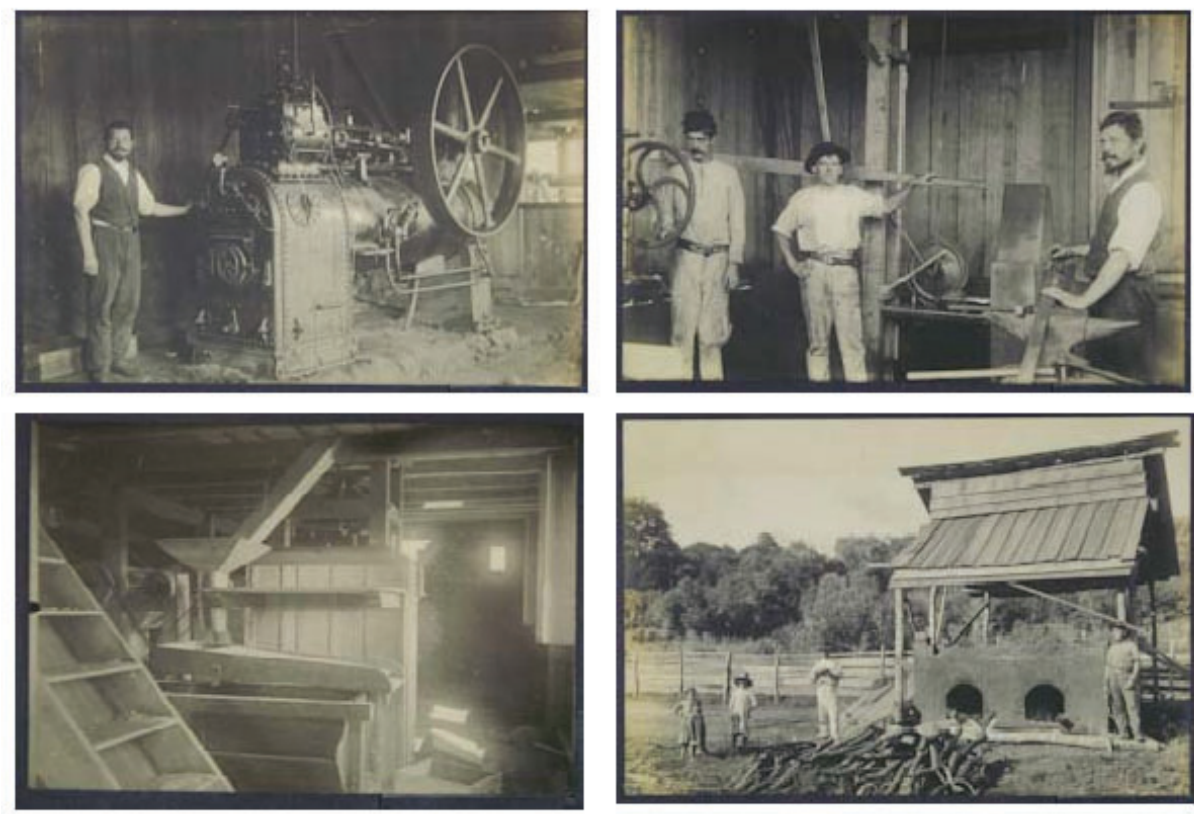

Fonte: SPI, 1942-1967.

\section{A escola do Posto}

Com o início das atividades no PI Apucarana, também se estruturou a escola do Posto, a partir de dezembro de 1942, ainda em prédio provisório, mas que já contava com a participação de 24 alunos, sendo 15 estudantes indígenas e os demais não-indígenas (SPI, 01/01/1943, Filme 47, Fotogramas 136-137). Essas informações repassadas pelo encarregado Francisco Gracia não foram confirmadas pelo inspetor do SPI, Deocleciano de Souza Nenê, meses após. Em visita ao PI Apucarana, o inspetor Nenê verificou [...] ser pouca a frequência de alunos, especialmente de indinhos, que é, pode se dizer: nula, pois encontrei no livro de matrícula 9 índios matriculados (SPI, 20/07/1943, Filme 47, Fotograma 162).

O inspetor informou que apenas duas meninas indígenas frequentavam as aulas e a distância da escola para os Toldos e a própria resistência dos indígenas eram os principais motivos da baixa frequência. Nenê ainda citou o exemplo que os alunos indígenas não gostavam do leite de vaca ofertado na escola, bem como de um aluno matriculado que não frequentava porque estava com reumatismo, mas seus pais não aceitavam ir ao médico em Londrina para se curar. E, por último, que os Toldos com mais indígenas - Apucarana e Rio Preto - eram muito distantes da escola 
e que o certo era pensar em construir escolas nesses locais (SPI, 20/07/1943, Filme 47, Fotograma 163).5

Independente da adesão dos alunos indígenas, o SPI buscou mobiliar a escola, conforme o pagamento realizado a Bento Soares Machado, de Cr\$368,00, pela confecção de diversos móveis para a escola do Posto (SPI, 31/07/1943, Filme 47, Fotograma 48). Ao final de 1943, João Martins Neto prestou a informação de que a escola funcionou durante o ano, com 12 alunos índios, 11 nacionaes, sob a regência da auxiliar de ensino Julia Guimarães Martins. Média de frequência 15 (SPI, 31/12/1943, Filme 47, Fotograma 224).

Quadro 6 - Fotografias da escola e dos alunos no PI Apucarana
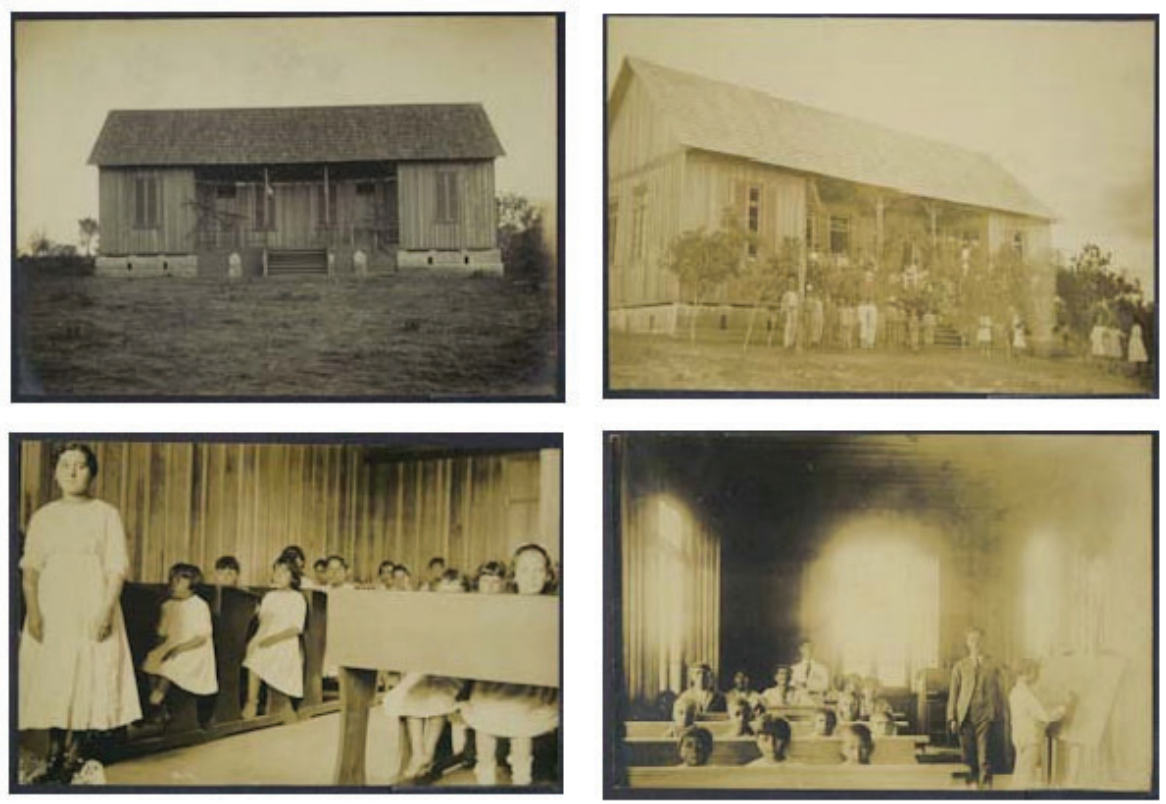

Fonte: SPI, 1942-1967.

No ano seguinte, João Martins Neto trouxe novos dados sobre a escola:

Funcionou durante o ano com pequena matrícula, frequentando assiduamente os alunos que residem próximo ao Posto, a matrícula e frequência são pequenas porque a maioria dos índios residem muito distante do Posto (alguns até a 40 quilometros), os alunos estão dispostos e são alimentados (um almoço) pelo Posto (SPI, 16/12/1944, Filme 47, Fotograma 592).

No Relatório Mensal de Novembro de 1945, João Martins Neto informou que a escola funcionou com baixo número de alunos matriculados, com frequência apenas daqueles que moravam próximo à sede do Posto. Segundo o encarregado, [...] a matrícula e frequência são pequenas devido a maioria dos índios residirem muito distante deste Pl. Alguns até 40 quilometros. Os alunos são alimentados e vestidos pelo Posto (SPI, 30/11/1945, Filme 49, Fotograma 417).

5 O Mapa 1 auxilia na visualização e compreensão das distâncias entre os Toldos e a sede do PI Apucarana. Nesse caso, em 1943, a sede se encontrava nas proximidades do Toldo Campina. 
Escola e trabalho no posto indígena apucarana: indigenismo e ação kaingang

No Ofício $\mathrm{n}^{\circ}$ 10, de 31 de março de 1946, João Martins Neto informou ao diretor do SPI que a escola do PI Apucarana contava com 14 matriculados, com frequência média e todos recebendo alimentações na escola (SPI, 31/03/1946, Filme 47, Fotograma 1759). Dois meses depois, o encarregado, por meio do Ofício $\mathrm{n}^{\circ} 17$, comunicou que a escola continha 17 matriculados e frequência média de 11,5 (SPI, 31/05/1946, Filme 47, Fotograma 1834). Nota-se que nestes últimos documentos não houve a distinção entre alunos indígenas e não-indígenas.

Como a frequência escolar era mínima por parte dos estudantes indígenas, o encarregado do Posto enviou duas propostas para a construção de uma escola no Toldo Rio Preto, que possuía um número maior de crianças indígenas (SPI, 23/02/1946, Filme 47, Fotogramas 1714-1717). De toda forma, essas escolas não saíram do papel, permanecendo a baixa frequência, como mostra o Ofício $n^{\circ} 7$, de 31 de março de 1948, com total de 11 alunos matriculados na escola (SPI, 31/03/1948, Filme 48, Fotograma 807), e nos Relatórios Mensais de janeiro a dezembro de 1950, que apresentaram a informação de 11 alunos matriculados, sendo apenas 3 indígenas (SPI, 1950, Filme 48, Fotogramas 1495-1515).

A mudança da sede do Posto também significou a construção de uma nova escola no final do ano de 1952. Segundo Alan Cardec, as aulas iniciariam em janeiro de 1953, mas que ainda necessitava a nomeação de uma professora. Além disso, solicitou [...] verba para 25 refeições das crianças, (um almoço) em face de a maioria, morar distante do Posto (SPI, 31/12/1952, Filme 48, Fotograma 1646).

Uma prática também comum do SPI era as aulas para toda a comunidade indígena. Eram chamados todos da área indígena para a organização de uma reunião, uma aula de civilização (SPI, 31/03/1953, Filme 48, Fotograma 1699). Essa prática ia ao encontro da política planejada pelo órgão indigenista, utilizando-se da pedagogia da nacionalidade e do civismo, como afirma Souza Lima (1995), na perspectiva de transformar o índio em trabalhador nacional.

Entretanto, a dificuldade era trazer os indígenas para a escola. No Relatório Mensal de dezembro de 1953, Alan Cardec indicou a frequência escolar com 10 alunos indígenas participando das aulas e mais 12 não-indígenas (SPI, 31/12/1953, Filme 48, Fotograma 1740).

Por meio do Ofício n 10, de 25 de maio de 1957, Alan Cardec informou que a escola se encontrava na sede do PI Apucarana, funcionando normalmente nos dias úteis, com horário sazonal: durante o inverno as aulas eram a tarde e no verão de manhã, comandadas pela auxiliar de ensino Ivete Maria da Encarnação Barbosa. 0 documento demonstra a matrícula de 8 alunos indígenas e outros 8 não-índios, mas indica que no segundo semestre outras 6 crianças indígenas estudariam na escola, [...] cujas famílias virão residir nas proximidades de nossa sede (SPI, 25/05/1957, Filme 49, Fotograma 73).

O encarregado ainda apontou os conteúdos ministrados na escola durante as aulas: [...] aulas preliminares sobre português, aritmética, pequenas noções sobre a descoberta do Brasil, hino nacional, hino a bandeira, uma vez por semana uma aula 
de costura para as meninas; e para os meninos, noções sobre lavouras, etc. (SPI, 25/05/1957, Filme 49, Fotograma 73). Conforme Oliveira e Freire (2006), a escola, com os rituais cívicos, do aprendizado de trabalhos manuais, de lições sobre pecuária e práticas agrícolas, buscava preparar o índio para o mercado de trabalho regional, ou seja, os métodos pedagógicos utilizados, caracterizava a escola como formadora de trabalhadores rurais, misturando as crianças indígenas com os filhos dos colonos na mesma sala de aula.

Os números da frequência escolar variam bastante nos documentos produzidos pelo SPI no PI Apucarana. Obviamente, essa variação contínua devia-se também às dinâmicas internas e às migrações dos indígenas entre os Pls. Como exemplo, entre janeiro e maio de 1957, eram 8 alunos indígenas, sendo 6 Kaingang e 2 Xetá. Entre junho a outubro, eram 16 alunos, sendo 11 Kaingang, 2 Xetá, um Guarani e 2 não-índios, mas em agosto um aluno indígena, de nome João, deixou de ir à escola, pois sua família saiu cladestinamente do Posto durante aquele mês. Já no mês de novembro, eram 10 alunos, sendo 8 Kaingang e 2 Xetá (SPI, 1957, Filme 49, Fotogramas 135-158).

Com o passar dos anos, houve uma concentração maior dos Kaingang nas proximidades na sede do PI Apucarana. Em maio de 1965, a professora de ensino, Amélia Tracz, deu informações de 40 alunos índios na escola do Posto (SPI, 31/05/1965, Filme 69, Fotogramas 20-21). Nesse mesmo sentido, o Ofício $\mathrm{n}^{\circ} 46$, de 10 de outubro de 1966, comunicou a frequência de 21 alunos indígenas, mas que precisava ser construída outra sala de aula, porque tinha 54 crianças com idade escolar na área indígena, que só não frequentavam porque a sala existente já estava lotada (SPI, 10/10/1966, Filme 69, Fotograma 162-163). Como enfatizou Oliveira (1985), a política indigenista tinha a ideia de transitoriedade do índio e o SPI via a escola como a principal forma de transformar os silvícolas em civilizados.

Nas palavras de Souza Lima (1995) estava orquestrado o Grande cerco de paz, em que a escola e o trabalho, presentes nos Postos Indígenas, correspondiam a mais uma etapa da Guerra de Conquista estabelecida pela ordem colonial. No entanto, é necessário analisar não apenas a ação estatal e de seus representantes, que visavam impor aos povos indígenas o modo de vida do não índios, como se os Kaingang nada fizessem e apenas se submetessem à ação do poder tutelar.

\section{A política indígena dos Kaingang do Apucarana}

As informações constantes nos documentos analisados permitem também revelar as ações da comunidade indígena do PI Apucarana, suas estratégias em defesa dos seus objetivos e seus territórios, evidenciando a política indígena em contraponto à política indigenista. Política de aproximação à sede do $\mathrm{PI}$, com relações amistosas, de aproveitamento da estrutura do Posto, benefícios financeiros, privilégios, aquisição de objetos, alimentos, entre outros. Mas também de distanciamento, fugas, enfrentamentos e conflitos, perante as situações cujos interesses eram divergentes 
aos dos representantes do SPI. Política de alianças com os arrendatários, os colonos em geral, não se submetendo aos mandos do encarregado do $\mathrm{Pl}$, até mesmo desafiando-o.

São situações históricas que inviabilizam as abordagens dualistas da história entre indígenas e não indígenas, retratando a complexidade das relações entre os sujeitos históricos envolvidos, demonstrando que, se por um lado, o órgão indigenista estruturou suas ações de criação e desenvolvimento do PI Apucarana, por outro, os Kaingang também elaboraram estratégias políticas.

\section{Trabalho e pagamento aos indígenas}

O encarregado João Martins Neto, por meio do Demonstrativo de Renda Indígena do mês de maio de 1943, demonstrou pagamentos a alguns índios do PI Apucarana, pelo serviço de quebrar milho. Entre eles, os índios Lindolfo, Tunico, Arlindo e Arthur Crespo, respectivamente 20, 15, 25 e 20 Cr\$ (SPI, 30/05/1943, Filme 47, Fotograma 38).

Como se vê, as atividades realizadas pelos indígenas eram diversas, de quebra de milho, roçadas, retiradas de palanques para cercas, entre outros serviços. Em 24 de julho de 1943, o então chamado Feitor Eduardo Stein apresentou a Relação nominal dos trabalhadores na construção da estrada de rodagem da séde do Posto em Campinas à Vila de São Roque, com o nome de 5 índios (Arthur Crespo, Anibal, João, Benedicto, Joaquim Rocha), cada um recebendo $\mathrm{Cr} \$ 6,00$ por dia de serviço (SPI, 24/07/1943, Filme 47, Fotograma 55). Em 31/08/1943, o encarregado do PI Apucarana pagou ao índio Arthur, por 144 de palanques de cerne, no total de Cr\$ 50,00 (SPI, 31/08/1943, Filme 47, Fotograma 68). Esses trabalhos no Posto, contando com a mão de obra indígena, eram muito comuns, presentes em vários documentos do SPI.

O fato é que os índios já eram listados na Folha de Pagamento como operários, com valor da diária definido e recebiam conforme a quantidade de dias trabalhados no mês. Também recebiam por tarefas esporádicas como o pagamento ao Índio Joaquim, em 10 de setembro de 1943, pelo transporte de palanques até a sede do PI Apucarana, no valor de $\mathrm{Cr} \$ 27,00$. No dia seguinte, o pagamento foi ao índio Anibal, por serviços na lavoura, no valor de $\mathrm{Cr} \$ 35,00$. E, no dia 30 de setembro, o índio Arthur recebeu $\mathrm{Cr} \$ 85,00$ por transportar palanques e rachões para a sede do Posto (SPI, 30/09/1943, Filme 47, Fotograma 91).

No Relatório Anual dos serviços prestados no PI Apucarana, durante o ano de 1943, João Martins Neto apresentou os dados da produção do Posto, enfatizando a mão de obra dos indígenas, que [...] roçaram e plantaram 200 hectares de terra, para o plantio de milho, arrôs e feijão (SPI, 31/12/1943, Filme 47, Fotograma 221).

Em visita ao PI Apucarana, em 1948, o inspetor Nenê elaborou seu Relatório e enviou à IR7, observando sobre as atividades realizadas pelos índios: 
Sobre o trabalho dos índios e feitio de roças [...] os índios não trabalham de graça, nem seria licito se aproveitar o serviço deles e não pagar seus serviços, quando a finalidade do SPI é ensinar, orientar e assistir os índios, motivos que em todos os Postos desta IR adota-se o feitio de roças para dar ganho aos índios, despertar neles o interesse de trabalhar para ganhar, a fim de não se tornarem parasitas, nem mendigos injustificáveis, sendo com são, homens fortes e sadios, e portanto aproveitáveis. As roças dos Postos servem, assim, para manutenção dos $\mathrm{PI}$, dar renda, e principalmente dar serviços aos índios (SPI, 18/02/1948, Filme 71, Fotogramas 312-313).

\section{Quadro 7 - Fotografias de indígenas trabalhando no PI Apucarana}
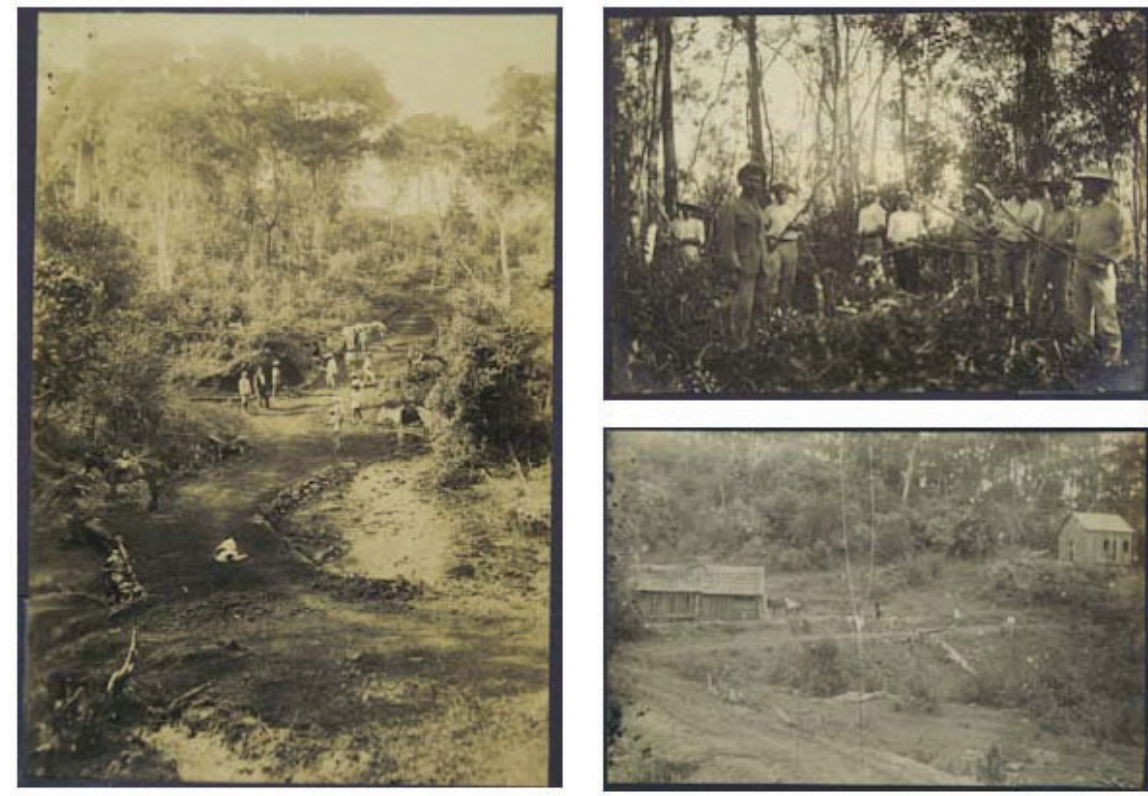

Fonte: SPI, 1942-1967.

Quadro 8 - Fotografias de índias preparando farinha de milho e índios na atividade com suínos no PI Apucarana
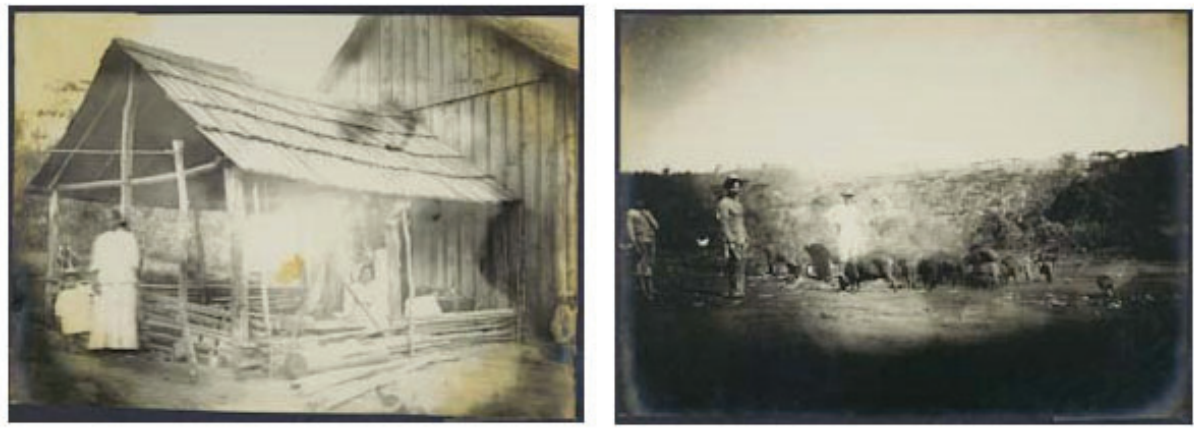

Fonte: SPI, 1942-1967. 
Nas relações estabelecidas entre o SPI e a comunidade indígena local, interesses convergentes poderiam coexistir nas atividades realizadas no PIApucarana. Entretanto, tais convergências não imperavam no cotidiano do Posto, como será demonstrado mais à frente. Essa análise só pode ser realizada se reduzir as escalas de abordagem, como orienta Bensa (1998), percebendo que as sociedades não constituem blocos compactos, mas regimentadas com múltiplas estratégias que se entrecruzam nos locais de interlocução, desafios e tensões. Contudo, é necessário estabelecer conexões entre as diferentes escalas de abordagem, ou, como argumenta Wolf (2005), relacionar o macro e o micro-nível, compreendendo as transformações nas sociedades e suas culturas, seu processo de negociações em cada contexto e como estabelecem suas relações sociais.

Nessa perspectiva, além dos trabalhos no Posto, os indígenas produziam alguns objetos para a venda, como mostra o Ofício $\mathrm{n}^{\circ}$ 7, de 31 de março de 1948, enviado pelo encarregado do PI Apucarana, ao diretor do SPI, apresentando uma planilha de vendas realizadas pelos Kaingang daquele Posto, revelando uma prática tradicional e ainda atual: a venda de artesanato (SPI, 31/03/1948, Filme 48, Fotograma 807).

Além dos serviços e atividades realizados no interior da área pertencente ao $\mathrm{PI}$, alguns Kaingang realizavam trabalhos fora do território destinado a eles, em propriedades rurais vizinhas, como mostra a Correspondência enviada por Alan Cardec à IR7.

\begin{abstract}
Em se tratando da foto que aparece uma índia junto com sua filhinha, encontra-se a mesma colhendo algodão, e não dentro das matas a procura de alimento, conforme cita o referido jornal. Esta índia pertence a tribo Guarany, natural do Estado de São Paulo, que aqui chegou no mez de abril a procura de uns parentes de seu marido, o qual pertence a tribo Caingang; como não encontrou os parentes, foi acolhida por esta administração, e dado licença para que trabalhe na colheta de algodão do Snr. Lindo, morador visinho deste Posto (SPI, 30/07/1951, Filme 48, Fotograma 1572).
\end{abstract}

Os índios também prestavam serviços às serrarias instaladas no interior ou nas proximidades da área indígena, desde serviços diretamente associados ao corte e retirada da madeira, como ainda na conservação de estradas para o transporte das madeiras extraídas do PI Apucarana. O Recibo de Pagamento executado pela Serraria Moacyr Vianna e Cia Ltda, no valor de Cr\$5.000,00, datado em 31 de agosto de 1955, era proveniente de [...] serviços prestados pelos índios na conserva de estradas as serrarias S. Roque e S. José, no corrente mez de Agosto (SPI, 31/08/1955, Filme 48, Fotograma 1919).

Isso demonstra uma série de atividades realizadas pelos indígenas do PI Apucarana, para o órgão indigenista, para as serrarias, nas propriedades vizinhas da área indígena e em suas próprias porções de terras. Em muitas dessas atividades, os índios utilizavam ferramentas próprias e requisitavam novas junto ao SPI, conforme demonstra o Relatório Mensal de 31 de outubro de 1957.

Nos trabalhos de roçadas no corrente mez, serviços este que vem sendo feito pelos índios deste PI, verificou-se a quebra de 11 foices, as quais pertenciam 
aos índios. Como este Posto não dispõe de ferramentas para indenizar os índios prejudicados, solicito nos seja remetido com uma certa urgência duas dúzias de foices afim de não sofrermos solução de continuidade na boa marcha de nossos trabalhos (SPI, 31/10/1957, Filme 49, Fotograma 122).

Quatro meses depois, continuava o encarregado do Posto com suas reivindicações de ferramentas para os serviços do PI Apucarana, [...] visto o Posto não dispor de recursos para compra das mesmas, e os nossos índios não querer trabalhar com as ferramentas deles, e que aliaz, acho muito justo (SPI, 28/02/1958, Filme 49, Fotograma 162).

Dessa forma, se por um lado o órgão indigenista buscava colocar em prática a ideia de transformar o índio em trabalhador rural, por outro lado, os indígenas interpretavam essas ações à sua maneira, aproveitando a estrutura do Posto, para obter vantagens, desde objetos, ferramentas, alimentos e ganhos financeiros.

O Plano de Assistência Agrícola para a Comunidade Indígena do PI Apucarana, apresentado pelo encarregado Alan Cardec à IR7, em 14 de agosto de 1962, por meio do Ofício $n^{\circ} 7$, evidencia a complexidade dos interesses entre o SPI e os índios. O Plano solicitou a compra de maquinário e ferramentas para o Posto, além do [...] financiamento ou fornecimento de alimentação para 40 famílias indígenas de no mínimo CR $\$ 30.000,00$ (trinta mil cruzeiros) para cada família (SPI, 14/08/1962, Filme 68, Fotograma 2060).

Alan Cardec seguiu descrevendo seu Plano:

Não obstante o alto custo de vida que atravessamos, era de se esperar que nossa tribo viesse a melhorar um pouco mais o seu padrão de vida, e a Administração deste Posto adquirisse com tais medidas, maiores e melhores possibilidades de manter os seus índios dentro de sua área, evitando que os mesmos saíssem a procura de trabalho em fazendas visinhas, o que nos acarreta sérios problemas (SPI, 14/08/1962, Filme 68, Fotograma 2061).

O fato é que o órgão indigenista não conseguia manter os índios apenas no interior da área indígena, mesmo ofertando possibilidades de ganhos com os trabalhos no Posto. Destarte, o encarregado sugeriu tal Plano seguindo os princípios de tutela que caracterizavam a política indigenista do SPI.

\footnotetext{
Seria interessante frisar que a Administração deste PI se limitaria apenas a supervisionar e orientar o plano de trabalho agrícola dos citados índios, desde a planta as colheitas, fiscalização de vendas, liquidação de débitos oriundos de fornecimento ou financiamento das lavouras. Quanto ao saldo líquido, seria pertencente exclusivamente a família indígena e não ao Posto. [...] não seria justo tomar como Renda Indígena, aquilo que foi produzido pelo índio (SPI, 14/08/1962, Filme 68, Fotograma 2061).
}

Alan Cardec sabia que, de outra forma, não conseguiria executar o Plano Agrícola, pois os indígenas não aceitariam trabalhar com parte da produção destinada ao Posto. Era preciso alimentos, ferramentas e produção para o próprio indígena. Desse modo, pode-se afirmar que o PI Apucarana foi sendo estruturado com o trabalho da mão de obra indígena, que realizava atividades diversas, como demonstra o Ofício $\mathrm{n}^{\circ} 35$, de 22 de novembro de 1965, quando diz que [...] os últimos dois índios, 
Lidio Mariano Martins e Osvaldo Pereira Gomes, continuam trabalhando na limpa da lavoura do Posto, atendem criações, etc., a fim de não paralisar os serviços diários do Posto (SPI, 22/11/1965, Filme 69, Fotograma 31).

\section{Alimentos e objetos aos indígenas}

Como já demonstrado, além das atividades remuneradas realizadas no $\mathrm{PI}$ Apucarana e das vendas de produtos, os indígenas recebiam alimentos, ferramentas e demais objetos do órgão indigenista. O Demonstrativo da Renda Indígena, de julho de 1943, apresentou um pagamento a Ernesto Machado dos Santos, [...] pela compra de três sacos de arroz, destinados à manutenção de escolares indígenas e índios necessitados (SPI, 31/07/1943, Filme 47, Fotograma 48). Também um pagamento a Araújo \& Cia, pelo fornecimento de mantimentos aos índios necessitados e aos escolares (SPI, 31/07/1943, Filme 47, Fotograma 48). Neste mesmo mês, um Recibo de Pagamento de Cr\$700,00, do PI Apucarana, pela aquisição de roupas, cobertores e ferramentas aos índios necessitados (SPI, 19/07/1943, Filme 47, Fotograma 52).

Em novembro de 1943, um novo Recibo de Pagamento, realizado ao comerciante Otavio Lima, pelo fornecimento feito a diversos índios velhos no período de março a novembro de 1943, no valor total de Cr\$ 920,50 (SPI, 30/11/1943, Filme 47, Fotograma 127). Esses objetos e alimentos aos índios, por meio do PI, constaram no Relatório Anual de 1943, que apontou auxílios prestados aos indígenas, totalizando Cr\$2.338,50, uma [...] importância dispensada com mantimentos, roupas, etc. aos índios deste Posto (SPI, 31/12/1943, Filme 47, Fotograma 221).

Apesar da maioria dos Toldos estar distante do local onde se construía e se estruturava a Sede do PI, muitos indígenas se aproximavam dos representantes do órgão indigenista e buscaram se beneficiar daquilo que o Posto podia Ihes oferecer. $\mathrm{Na}$ citada visita do inspetor Deocleciano de Souza Nenê ao PI Apucarana, ele descreveu que havia [...] um monjolo mandado fazer para o índio Paulino Rodrigues dos Santos (Garãm) (SPI, 20/07/1943, Filme 47, Fotograma 164).

Casas também foram construídas aos índios, conforme a Relação dos Imóveis existentes no PI Apucarana, em 1945. Segundo este documento, 26 casas foram construídas de madeira lascada, de diversos tamanhos, e entregues aos índios, a $\mathrm{Cr} \$ 800,00$ cada uma, pagos pelo órgão indigenista, totalizando $\operatorname{Cr} \$ 20.800,00$ (SPI, 23/02/1945, Filme 47, Fotogramas 901-902).

Em 30 de junho de 1946, João Martins Neto enviou o Ofício n 22 ao Dr. José Maria de Paula, diretor do SPI, informando que deu um presente ao índio Gregório: [...] mandei fazer uma cangalha e dei ao índio acima referido, pois aquele índio merece é muito trabalhador e presta bons serviços como Capitão do Toldo Apucarana (SPI, 30/06/1946, Filme 47, Fotograma 1838).

Os objetos e mercadorias eram fornecidas aos índios de forma contínua. Esses fornecimentos continuavam no ano de 1948, como mostra um Recibo de Pagamento 
na [...] importância supra de quatrocentos cruzeiros, proveniente de fornecimentos feitos em mercadorias diversas aos índios escolares e a diversos índios velhos (SPI, 29/02/1948, Filme 48, Fotograma 628).

Quadro 9 - Fotografias de casas dos Kaingang no PI Apucarana
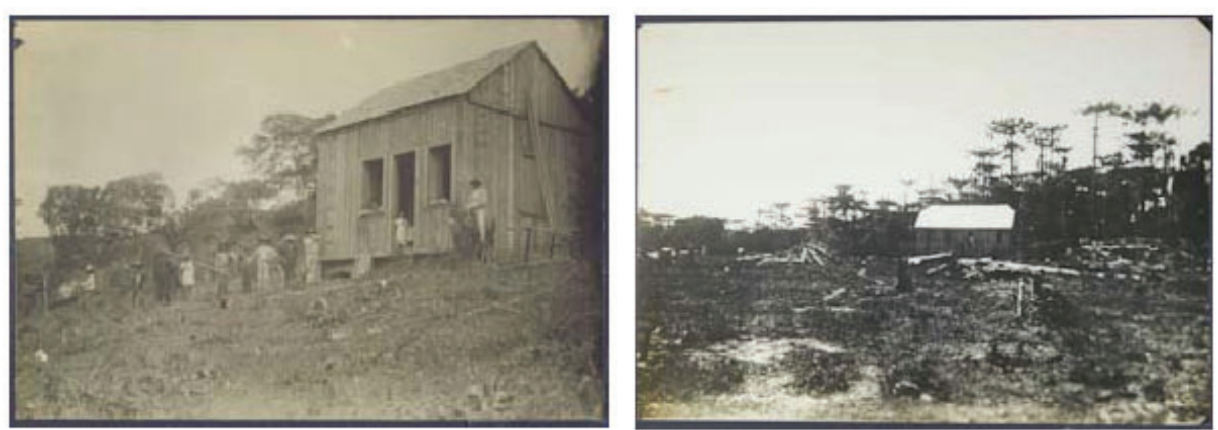

Fonte: SPI, 1942-1967.

Há ainda uma Nota Fiscal emitida pela empresa Casa São Paulo, de Curitiba, em nome do SPI, que comprova os [...] fornecimentos feitos de fazendas em geral para os índios velhos e inválidos do Posto Indígena Apucarana (SPI, 31/03/1948, Filme 48, Fotograma 634), no valor total de Cr\$2.587,50. Entre os itens da Nota Fiscal, estavam cobertores, tecidos diversos, botões, carreteis de linhas, pares de sapatos, camisas etc.

Os deslocamentos dos indígenas, mesmo que provisório, até próximo à sede do Posto, despertavam a preocupação do encarregado em construir casas aos índios. Esses saíam de seus Toldos em busca de alguns recursos disponíveis na sede do PI Apucarana.

Temos também o problema de habitação para os índios, em consequência de termos mais de dez famílias que estão morando quase ao relento. Afim de que esta administração possa tomar uma iniciativa, solicito de V.S. instruções em torno destas necessidades (SPI, 30/04/1951, Filme 48, Fotograma 1478).

Quando ocorreu a mudança da sede do Posto para o novo local, o encarregado Alan Cardec fez uma série de solicitações junto a IR7. Entre os itens, estavam [...] roupas e medicamentos para os índios (SPI, 08/10/1951, Filme 48, Fotograma 1583).

No Relatório Mensal de outubro de 1955, o encarregado do Posto informou sobre problemas de saúde dos indígenas, que cobravam por medicamentos do Posto.

\footnotetext{
Necessitamos de medicamentos para atender o estado de saúde dos nossos índios, visto a renda que este PI vem tendo, nestes últimos ser muito precária, deixando desta maneira o encarregado do Posto em situação bastante delicada diante da gravidade dos factos. Estão os índios sendo vitimados de grandes infecções em geral. Com uma boa partida de penicilina, enterrovioformio e sulfa-guanidine, possivelmente resolveremos a situação (SPI, 31/10/1955, Filme 48, Fotograma 1859-1960).
}

Entretanto, se alguns membros da comunidade indígena cobravam os medicamentos junto ao encarregado do Posto, para solucionar seus problemas de 
saúde, outros acabavam se esquivando da ação indigenista, quando das vacinas e aplicação de remédios, sobretudo, ao tratar de crianças indígenas.

Tendo este PI dado início a uma espécie de assistência social nos aldeamentos de toda esta reserva indígena, verifiquei a grande avitaminose existente no seio da infância indígena, muito especialmente, aquelas famílias que procuram esconder os filhos da assistência da Administração do Posto, (motivo medo de ingeção e de produtos farmacêuticos). No entanto, sugiro a V.S. remeter uma certa quantidade de vitaminas e cálcio via oral, tenho certeza que resolverei a situação destas crianças (SPI, 31/07/1956, Filme 49, Fotograma 14).

Em novembro de 1958, Alan Cardec comunicou novamente a IR7, sobre uma epidemia de fortes gripes seguida de pneumonia, gerando mortes de indígenas e transtornos para a administração do Posto, solicitando penicilina e demais medicamentos para uso adulto e infantil, porque já tinham muitos doentes. Mais uma vez o encarregado solicitou os remédios em gota, [...] afim de facilitar aplicação nas crianças de um a 12 anos de idade (SPI, 30/11/1958, Filme 49, Fotograma 180).

No que tange a saúde, além dos medicamentos, os indígenas utilizavam da estrutura do SPI para as viagens até as cidades com mais recursos para alguns específicos tratamentos. O Ofício $\mathrm{n}^{\circ} 35$, em 18 de março de 1960, demonstra a preocupação de Alan Cardec com uma criança indígena que sofreu mordedura de cão louco. Tratava-se de Sebastião Cardoso, filho do índio Rozendo Cardoso, que foi acompanhado do enfermeiro do PI Apucarana, Delfino Coutinho Costa, para Curitiba, conforme acerto via Serviço de Rádio entre o encarregado e o chefe da IR7, [...] por motivo de em Londrina os recursos para o referido caso serem muito precários, tomei a liberdade de encaminha-los diretamente a essa chefia, visto dessa capital existir maiores possibilidade para salvar a nossa criança (SPI, 18/03/1960, Filme 49, Fotograma 396).

Mesmo após o Golpe Civil Militar, a política indígena de se aproximar do órgão indigenista e de obter algumas vantagens proporcionadas por essa relação continuou. O Ofício $n^{\circ} 23$, de 31 de agosto de 1965, revelou a doação de alimentos, cobertores e tecidos aos índios.

Outrossim, conforme solicitação feita a essa Chefia, através do Rádio, o Sr. Chefe autorizou esta Administração contrair débitos no comercio, a fim de atender os índios que encontram-se no acampamento com a finalidade de fazerem roça coletiva, assim como também para adquirir cobertores e tecidos. Comunico a V.Sa., que até o presente momento adquirimos 11 sacos de feijão para alimentação dos índios no acampamento (SPI, 31/08/1965, Filme 69, Fotograma 027).

Novamente, a prerrogativa da alimentação, vestimentas e demais objetos para os indígenas trabalharem em suas roças individuais e coletivas. Além disso, o Relatório Mensal de 30 de setembro de 1965, demonstra a reivindicação dos indígenas por casas.

Sr. Chefe da IR7, o problema habitacional desta área indígena agrava-se cada vês mais, todavia, os índios aguardam com fé e esperança no Sr. Chefe da IR7 e no Sr. diretor do SPI, na concretização do Plano de Trabalho apresentado 
por esta Administração, em 12/7/65, assim sendo, serão sanados todos os problemas existentes neste Poind (SPI, 30/09/1965, Filme 68, Fotograma 2244).

Outrossim, os indígenas procuravam obter vantagens com a estrutura criada pelo SPI naquela localidade, reinventando novas formas de vida, como grupo que não se configura por uma cultura imutável e que produz estratégias políticas, pois, conforme Balandier (1987), não existe sociedade apolítica, já que todas são capazes de assimilar as transformações de um dado contexto histórico e planejar suas ações.

\section{Deslocamentos, tradições e reivindicações}

Como já abordado, os Kaingang mantinham seus deslocamentos constantes por toda a região do PI Apucarana e para outros PIs das bacias dos rios Tibagi e Ivaí, onde situavam os seus Toldos tradicionais. Essas ações dos indígenas dificultavam as atividades dos encarregados do Posto, como os recenseamentos e a fixação dos Kaingang na área a eles destinada. Eram idas e vindas não apenas pelos territórios reservados aos índios, mas por toda a região adjacente, visitando seus parentes nos Toldos de outras localidades. Como exemplo, o Memorando $n^{\circ} 4$, de 18 de janeiro de 1943, da IR7 ao PI Apucarana, quando abordou as solicitações referente a escola e ao trato com os índios, orientou ao encarregado: [...] deveis providenciar para recolher a essa área indígena os índios que estão em terra alheia, entre Londrina e São Roque, nas imediações da ponte sobre o rio Taquara (SPI, 18/01/1943, Filme 73, Fotograma 1524).

Também o Ofício n 10, de 31 de março de 1946, enviado por João Martins Neto ao diretor do SPI, no Rio de Janeiro, abordou o estado sanitário dos indígenas do PI Apucarana, informando a relação destes com os do PI Barão de Antonina, na outra margem do rio Tibagi.

[...] é aquele vai e vem para o PI Barão de Antonina. Quando vão para aquele Posto, tem por hábito de pernoitarem na barranca do rio, com o fito de pescarem, nessa pesca nas condições que está as margens do rio, que formou aqueles alagadiços e com este grandes calorão que tem havido estes últimos dias, está desenvolvendo uma febre terrível (SPI, 31/03/1946, Filme 47, Fotograma 1770).

Esses deslocamentos também podem ser observados no Ofício no 14, de 30 de abril de 1946, que tratou da Festa do Índio, realizada em 20 de abril daquele ano, um sábado que antecedia à celebração da Páscoa.

Convidei todos os índios desta reserva, para naquele dia virem para assistirem sua festa, porém, este ano vieram poucos relativamente, pelo motivo de estarem quase na maioria, em suas pescarias, que é de costume todos os anos pela Semana Santa. Só estiveram na festa 43 índios, entre homens e mulheres e crianças. A estes foi oferecido um farto almoço, composto de carne de porco, feijão, arroz, mandioca, abóbora, batata doce, etc. Para sobremesa foi dado leite com cangica e moranga. [...] A noite foi oferecido um grande baile embaixo de um empalisado 'ramada'. Para o baile forneci 
Se por um lado, uma parte pequena da comunidade indígena local participou da Festa do Dia do Índio, aproveitando toda a alimentação, doces e o próprio baile preparados pelo PI, por outro lado, as práticas tradicionais, como a pesca, mantinhamse vivas entre os índios, que conheciam o território, os rios e realizavam suas pescarias para a subsistência.

Em 1953, a Festa do Dia do Índio foi descrita pelo Relatório Mensal enviado a IR7, com a organização de uma grandioso almoço para os índios do PI Apucarana e de outros Postos, com longas rodas de conversa entre os índios e a noite um baile, em que foi exibida a dança do engenho [...] e outras mais de seus primitivos dias (SPI, 30/04/1951, Filme 48, Fotograma 1701). Dessa forma, a comunidade indígena do Apucaraninha apropriava-se da festa organizada pelo órgão indigenista e realizava suas danças e rituais tradicionais, recebendo seus parentes e amigos de outros Pls, prática ainda hoje comum na TI Apucaraninha.

Em 26 de fevereiro de 1950, por meio do Ofício n 42, o inspetor Deocleciano de Souza Nenê sugeriu ao chefe da IR7, a construção de um cômodo para os índios em Curitiba, entrando em contato com a Prefeitura Municipal da capital, para solicitar um lote de terras [...] no quadro suburbano, cedido ou aforado, em último caso comprado, em lugar não muito distante, para nesse lote mandar cercar e construir um galpão de uns 12x9 metros, ou seja, $98 \mathrm{~m}^{2}$ (SPI, 26/02/1950, Filme 70, Fotogramas 77-78). A justificativa do inspetor Nenê era:

Não há como vedar as constantes visitas de grupos de índios vindos de
várias regiões, não se devendo culpar os Encarregados dos Postos, porque,
como nós que já convivemos com os índios em Postos, bem conhecemos
como eles fazem para se sustentarem, ora com caçadas, ora com pescas
ou ainda em visita a outros toldos, e nessas ocasiões rumam para esta
capital e até para o Rio, como é disso conhecedora a nossa Diretoria, e aqui
chegam sempre sujos, rotos, muitas vezes em dias de feriados, que as casas
comerciais estão fechadas, [...] e por esse motivo nenhum hotel ou pensão
querem arranjar cômodo, sendo como sabeis incomodo, aborrecimentos e
acrescendo despesas (SPI, 26/02/1950, Filme 70 , Fotograma 77 ).

Como se vê, os índios se deslocavam para Curitiba e até para o Rio de Janeiro, fazendo determinadas exigências junto ao órgão indigenista. O Memorando $n^{\circ} 314$, enviado pela Diretoria do SPI, no Rio de Janeiro, para a IR7, em Curitiba, no dia 12 de julho de 1956, revelou um dos motivos das idas e vindas dos representantes indígenas por aquelas localidades.

Com o presente, apresento-vos os Índios Kaingang: Sebastião Kaingang, Francisco Índio do Brasil e Tonico Bório, os quais compareceram a esta Diretoria, a fim de pleitearem medidas protetoras com respeito às terras aonde residem, para o que peço a vossa atenção (SPI, 12/07/1956, Filme 70, Fotograma 838).

Os indígenas tinham conhecimento das instâncias superiores do órgão indigenista e se articulavam para se deslocar até a diretoria do SPI, caso achassem necessário. Até mesmo se portavam diretamente ao presidente da República, como 
demonstra o Telegrama $n^{\circ} 344$, de 30 de outubro de 1944, enviado pela Assessoria da Presidência à Diretoria do SPI.

\begin{abstract}
Joaquim Gabriel França, Francelina Donaria Donalícia solicitaram passagens presidência da república três índios e um guia para virem a esta capital expor o maus tratos infligidos agente PI Apucarana. Informai máxima urgência o que verdade há afim esclarecer a respeito (SPI, 30/10/1944, Filme 71, Fotograma 535).
\end{abstract}

Essas ações causavam transtornos as diferentes instâncias do órgão indigenista e revelam as estratégias dos indígenas perante as medidas adotadas pelo encarregado do Posto e demais representantes do SPI. Inúmeras vezes, o órgão indigenista visou barrar esses deslocamentos, orientando seus empregados a não deixar os indígenas saírem de suas áreas delimitadas e terem um controle regulado das eventuais necessidades dos deslocamentos. Entretanto, os índios elaboravam estratégias para obter autorização do PI, oficializando suas saídas, sendo que, muitas vezes, demoravam para o retorno ou nem retornavam, como demonstra o Ofício $\mathrm{n}^{\circ} 4$ de 26 de abril de 1961, enviado pelo PI à IR7.

Todavia, para maior esclarecimento desta Administração, solicitaria dessa IR, informar se podemos continuar fornecendo ordens para os nossos índios venderem seus produtos e faserem comprar nas Vilas de nosso Distrito conforme vinha sendo feito, ou devemos seguir o rigor da Guia de Licença oficial (SPI, 26/04/1961, Filme 68, Fotograma 1990).

Outra ação adotada pelos indígenas eram as solicitações de transferência para outros Pls, que não era apenas uma forma de punição pelo órgão indigenista, mas também utilizada pelos indígenas, para o encontro e convívio com seus parentes, entre outros objetivos. Essas transferências eram comuns, como revela o Relatório Mensal, de 31 de maio de 1966, indicando a transferência de 7 índios, do PI Apucarana para o PI Duque de Caxias (SPI, 31/05/1966, Filme 69, Fotograma 40) e a chegada de outros 7 Kaingang no PI Apucarana, conforme Relatório Mensal de 30 de setembro de 1966 (SPI, 30/09/1966, Filme 69, Fotograma 47).

\title{
Considerações Finais
}

Conforme Monteiro (1999, p. 248) não basta mais caracterizar o índio histórico simplesmente como vítima que assistiu passivamente à sua destruição ou, numa vertente mais militante, como valente guerreiro que reagiu brava porém irracionalmente à invasão europeia. É preciso demonstrar o protagonismo do sujeito histórico indígena, sua compreensão dos mecanismos de funcionamento da sociedade não-indígena, que subsidiou suas ações na história do Brasil. Também se faz necessário analisar as relações sócio históricas dos indígenas com os demais sujeitos, pois como afirma Oliveira (2016, p. 7) a preocupação não pode ser a de [...] delimitar unicamente uma história dos indígenas, mas sim, em refletir sobre conjuntos de relações estabelecidas entre os indígenas e os demais atores e forças sociais que com eles interagiam. 
Obviamente o pensamento homogeneizante, que não concebia qualquer distinção na tratativa com os povos indígenas do Brasil, era a base do regime de tutela, controlado pelos representantes do SPI. Destarte, as ações coordenadas pelo encarregado do PI Apucarana revelaram as tentativas de transformar o indígena num sujeito civilizado e trabalhador, que auxiliava nas atividades do Posto, nas plantações, no trabalho com os animais, colocando os filhos na escola etc.

Contudo, as ações dos Kaingang do PI Apucarana revelam o protagonismo indígena. Inicialmente alguns índios se aproximaram da estrutura da sede do Posto, realizando alguns trabalhos e obtendo algumas vantagens com a presença do órgão indigenista, recebendo alguns objetos, vestimentas, alimentos, remédios, entre outros. Entretanto, outros permaneceram distantes, em seus Toldos tradicionalmente ocupados, que raramente eram visitados pelos agentes do SPI. A história do PI Apucarana deixou evidente a impossibilidade de caracterizar as relações entre índios e não-índios de forma simplesmente polarizada. A narrativa demonstrou as complexidades, as nuances, os conflitos, as alianças, as clivagens e o jogo de interesses entre os sujeitos envolvidos. A história aqui proporcionada evidenciou as diferentes ações dos Kaingang perante o contexto de uma nova fase da Guerra de Conquista, com o desenvolvimento de políticas próprias para defender seus territórios e reivindicar seus direitos.

\section{Referências $^{6}$}

BALANDIER, Georges. Antropologia política. Lisboa: Editorial Presença, 1987.

BENSA, Alan. Da micro-história a uma antropologia crítica. In: REVEL, Jacques. Jogos de Escala. Rio de Janeiro: FGV, 1998. p. 39-76.

CUNHA, Manuela Carneiro da. (Org.). História dos índios no Brasil. São Paulo: Cia. das Letras, 1992.

GAGLIARDI, José Mauro. O indígena e a república. São Paulo: Hucitec, 1989.

MONTEIRO, John Manuel. Armas e armadilhas: história e resistência dos índios. In: NOVAES, Adauto. A outra margem do Ocidente. São Paulo: Companhia das Letras, 1999. p. 237-249.

NOVAK, Éder da Silva. Emã e Tekoha: territórios indígenas e a política indigenista. 1. ed. Curitiba: APPRIS, 2019. 233p.

6 A documentação do SPI, citada nesse texto, está presente no Museu do Índio, na cidade do Rio de Janeiro/RJ, disponível em microfilmes e fotogramas. São Relatórios, Ofícios, Memorandos, Telegramas, Fotografias etc. Em virtude da grande quantidade de documentos utilizada e do espaço definido para esse artigo optou-se em não listar a documentação nas referências. 
NOVAK, Éder da Silva. Os Kaingang e a reestruturação do Território Indígena Apucarana (PR) no século XX. Territórios e Fronteiras (ÚFMT. Online), v. 11, p. 279307, 2018.

OLIVEIRA, João Pacheco de. O nascimento do Brasil e outros ensaios: "pacificação", regime tutelar e formação de alteridades. Rio de Janeiro: Contra Capa, 2016.

OLIVEIRA, João Pacheco de. O nosso governo: os Ticunas e o regime tutelar. São Paulo: Marco Zero, 1988.

OLIVEIRA, João Pacheco de. Contexto e horizonte ideológico: reflexões sobre o Estatuto do Índio. In: SANTOS, Sílvio Coelho dos (Org.). Sociedades indígenas e o direito: uma questão de direitos humanos. Florianópolis: Ed. UFSC: CNPq, 1985, p.17-30.

OLIVEIRA, João Pacheco de; FREIRE, Carlos Augusto da Rocha. A presença indígena na formação do Brasil. Brasília: Ministério da Educação, Secretaria de Educação Continuada, Alfabetização e Diversidade. LACED/Museu Nacional, 2006.

ROCHA, Leandro Mendes. A política indigenista no Brasil: 1930-1967. Goiânia: Editora da UFG, 2003.

SOUZA LIMA, Antonio Carlos de. A 'identificação' como categoria histórica. In: OLIVEIRA, João Pacheco de (Org.). Indigenismo e territorialização: poderes, rotinas e saberes coloniais no Brasil contemporâneo. Rio de Janeiro: Contra Capa, 1998, p.171-220.

SOUZA LIMA, Antonio Carlos de. Um grande cerco de paz: poder tutelar e indianidade no Brasil. Petrópolis: Vozes, 1995.

SOUZA LIMA, Antonio Carlos de. O governo dos índios sob a gestão do SPI. In: CUNHA, Manuela Carneiro da (Org.). História dos índios no Brasil. São Paulo: Cia. das Letras: SMC/SP: FAPESP, 1992. p. 155-172.

WOLF, Eric R. A Europa e os povos sem história. Tradução de Carlos Eugênio Marcondes de Moura. São Paulo: EDUSP, 2005.

Recebido em abril de 2020.

Aprovado para publicação em abril de 2021. 